\title{
RES
}

Res Mobilis

Revista internacional de investigación en mobiliario y

objetos decorativos

Vol. 6, nº. 7, 2017

\section{RICARD DE CAPMANY, DECORADOR MODERNISTA EN BARCELONA RICARD DE CAPMANY, ART NOUVEAU DECORATOR IN BARCELONA}

Vicente de la Fuente Bermúdez* Colaborador de la Casa Museu Lluís Domènech i Montaner

\section{Resumen}

Ricard de Capmany, autor de una de las obras Modernistas más evocadoras y míticas, el desaparecido café Torino de Barcelona, es un gran desconocido del que, hasta ahora, se tenían pocos datos de su trayectoria. Mucho más que un decorador, Capmany se nos revela como un personaje poliédrico, un esteta que busca en el arte y en su obra más personal, el Castillo de Santa Florentina, sobreponerse a una realidad que le desagrada.

Palabras clave: Ricard de Capmany, Domènech i Montaner, decoración, modernismo.

\section{Abstract}

Ricard de Capmany, author of one of the more evocative and mythical Art Nouveau works, the disappeared coffee Torino in Barcelona, is a big unknown, up to now, we had few data of his life and work. Much more that a decorator, Capmany reveals us as a polyhedral character, an aesthete that overcome a reality that dislike him, with the art and his most personal work, the Castillo de Santa Florentina.

Keywords: Ricard de Capmany, Domènech i Montaner, interior decoration, Art Nouveau.

\footnotetext{
*E-mail: vicente.dlfuente@gmail.com
} 
Ricard de Capmany es uno de esos nombres recurrentes que aparecen en los estudios sobre decoración modernista; casi siempre asociado a la obra que más reconocimiento le ha dado: la decoración del café Torino en la Gran Via de les Corts Catalanes esquina Passeig de Gràcia de Barcelona.

Sin embargo, el estudio de su figura se ha visto lastrado por la falta de documentación y la carencia de un catálogo de obras lo suficientemente importante como para dotarlo de una entidad propia. Es cierto que no fue un decorador prolijo; trabajar para él era más una afición que una necesidad. Pero aún así las fotografías de algunos de sus trabajos, las decoraciones más o menos conservadas y la descripción de su personalidad trazada por su hijo, el pintor Ramon de Capmany, nos permiten intuirlo como el último gran romántico del siglo XIX, un buscador incansable de la belleza.

Para realizar esta pequeña biografía hemos recurrido a la prensa contemporánea, la visita de los espacios, aún conservados, que fueron decorados por él y a la escasa documentación que ha preservado la familia ${ }^{1}$.

\section{Estado de la cuestión}

Para la historiografía tradicional, Ricard de Capmany, aparece y desaparece con la decoración de los cafés Torino. Nada hay sobre su formación o trayectoria posterior.

Desde los primeros historiadores del arte en tratar el Modernismo como movimiento artístico, Cirici y Ráfols o los arquitectos Bohigas y Mackay hasta Galería de Autores. Ruta del Modernismo de Barcelona del 2008, esta última con múltiples errores y confusiones ${ }^{2}$, lo citan únicamente por su trabajo relativo al café Torino del Paseo de Gracia ${ }^{3}$. Ràfols lo destaca entre los arquitectos decoradores (Domènech, Puig i Cadafalch, Gaudí) que hacen que sus obras superen la pura imitación de un estilo "sub-Mucha", que se da en el resto de interioristas modernistas y cita en concreto, en este estilo, a Salvador Alarma y Gaspar Camps ${ }^{4}$.

Sólo desde el Centre de Documentació i Museu Tèxtil en la ciudad de Terrassa (provincia de Barcelona), Silvia Carbonell apunta su faceta como diseñador textil ${ }^{5}$ y desde la Canet de Mar, en la costa de Barcelona, yo mismo, su imparable actividad como decorador de arquitecturas efímeras y otros elementos de las fiestas populares de Canet de Mar, así como diseñador de joyas: la corona y la medalla elaboradas para las Fiestas de la Coronación Canónica de la Virgen de la Misericordia, en $1909^{6}$.

Pero quizás, su gran obra y más personal fue el castillo de Santa Florentina, residencia de la familia en Canet de Mar. Edificio del que nunca se ha llegado a delimitar hasta que punto el interior de éste es creación de Domènech i Montaner o Capmany, algo siempre difícil por la manera de trabajar del arquitecto, a veces con un férreo control de los elementos que elaboraban sus colaboradores, que actuaban como meros artesanos ejecutando sus diseños; otras 
ofreciéndoles total libertad creativa ${ }^{7}$. No hemos de olvidar, que en este caso, Capmany además de colaborador, era uno de los promotores de la obra.

En este artículo intentaremos ofrecer algunos datos, hasta ahora poco conocidos, que nos permitan definir un poco más la figura del Capmany decorador.

\section{Ricard de Capmany i Roure (Barcelona, 1871 - Canet de Mar, 1947)}

Nació el 12 de abril de 1871, en el seno de una acomodada familia barcelonesa; en el centro de la ciudad antigua, la calle Escudellers, recibiendo los nombres de Ricardo Pedro Esteban ${ }^{8}$. Su padre, Jacinto, era parte de una saga de comerciantes e intelectuales entre cuyos miembros destacó Antoni de Capmany ${ }^{9}$. $\mathrm{Su}$ madre, Francesca, originaria de Canet de Mar, y perteneciente a una rica familia de navegantes, era hermana de la esposa del arquitecto modernista Lluís Domènech i Montaner. En 1898 se casa con Júlia de Montaner i Malattó (Fig. 1), hija del editor Ramon de Montaner, tío de Domènech i Montaner ${ }^{10}$.

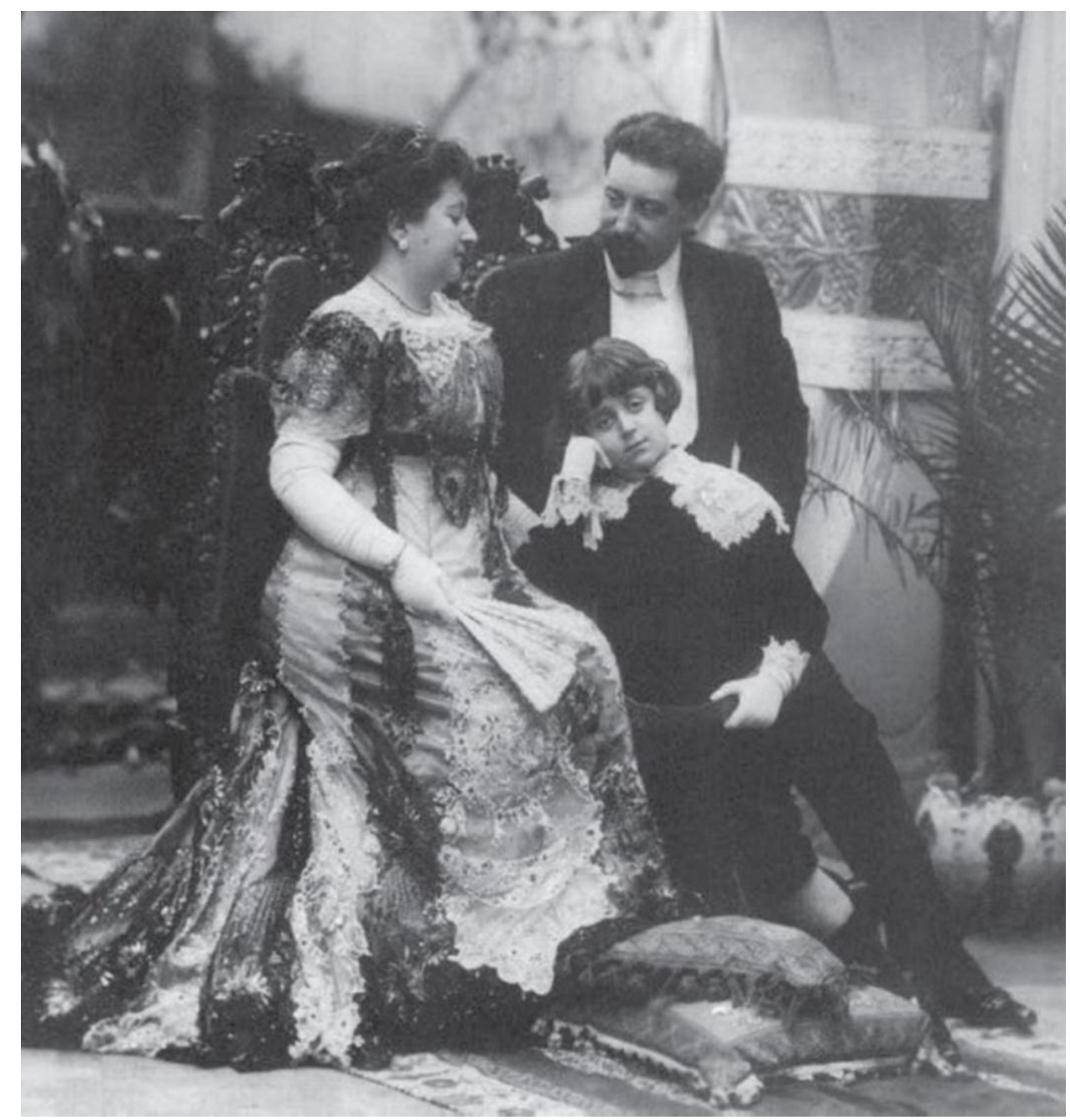

Fig. 1. Ricard de Capmany junto a su esposa Júlia de Montaner y el hijo de ambos, Ramon. Fotografía ca. 1908. Colección particular, Canet de Mar. 
Formado en la Escola d'Arts i Oficis de Barcelona, la primera obra conservada de él, posiblemente, es la decoración de la casa familiar en la calle Escudellers, aunque no está firmada. En diciembre de 1892, su madre solicita permiso al Ayuntamiento de Barcelona para estucar la fachada, decoración que se ha mantenido hasta el día de hoy. Se tratan de unos falsos tapices con decoración vegetal, en el que las figuras centrales son tondos con bustos de caballeros renacentistas. Un año después, se hace construir en el terrado de la finca un "taller-estudio" con planos firmados por Domènech i Montaner"1.

Respecto a las primeras informaciones que tenemos de su presencia en el panorama artístico barcelonés, vienen de su participación en las exposiciones de arte patrocinadas por el ayuntamiento de la ciudad. En 1894 en la Segunda Exposición General de Bellas Artes presenta el óleo Una nota Gris ${ }^{12}$; en la III Exposición de Bellas Artes e Industrias artísticas, envía la obra Por la fe expuesta en el Salón Reina Regente ${ }^{13}$, y, en el mismo certamen, pero del año 1898, el óleo Maig-Mayo ${ }^{14}$. En estas mismas fechas aparecía en el Anuario Riera bajo el epígrafe de "Pintores de cuadros"; en 1897 aún en la casa paterna de la calle Escudellers y, en 1901, ya en el Palau Montaner de la calle Mallorca, la residencia de su suegro, Ramon de Montaner.

Sin embargo, su mayor repercusión en prensa se debió a los proyectos decorativos por él ideados o en los que participó. En ese momento, la burguesía barcelonesa aspira a dotar a sus actos festivos de una calidad estética a la altura del resto de capitales europeas. Escenógrafos, decoradores y artistas se dedican a crear los marcos ideales de exhibición de esta enriquecida clase social, así como a la dignificación de las fiestas populares ${ }^{15}$, una labor en la que los Montaner/Capmany fueron pioneros en Canet de Mar, a imitación de lo que ocurría en Barcelona ${ }^{16}$. Así, Capmany participa en las decoraciones del baile de disfraces del Círculo Artístico de 1895, asociación de la que es miembro, siendo el responsable de realizar una colgadura en la que se representa una pareja del Renacimiento alemán, una elección nada casual, pues toda su obra respira la influencia de los siglos XV y XVI germánicos ${ }^{17}$. En 1902, es responsable, junto a Domènech i Montaner, del diseño de la pareja de gigantes y el cortejo de cabezudos y caballeros medievales, que el castillo de Santa Florentina (residencia de la familia en la localidad de Canet de Mar) presentó al concurso de gigantes celebrado en Barcelona, con motivo de las fiestas patronales de La Mercé, alzándose con el primer premio. La repercusión de estos gigantes en prensa fue abrumadora $^{18}$, se destacaba el realismo de los vestidos, la riqueza, y no solo de la pareja protagonista sino de todo el cortejo.

En la Exposición Industrial de Barcelona del año 1897, Capmany fue el responsable de la instalación de las Cervezas Comas y Cia ${ }^{19}$ (Fig. 2), de la que su hermano, Enric, era accionista y más tarde propietario ${ }^{20}$. Pero al margen de estos trabajos como pintor y diseñador, fueron sus primeros encargos como decorador de interiores los que podrían haber consolidado su figura profesional, por el éxito alcanzado: la decoración de los dos cafés Torino. Sin embargo, lejos de iniciar una exitosa carrera, representaron un punto y, casi, final. 


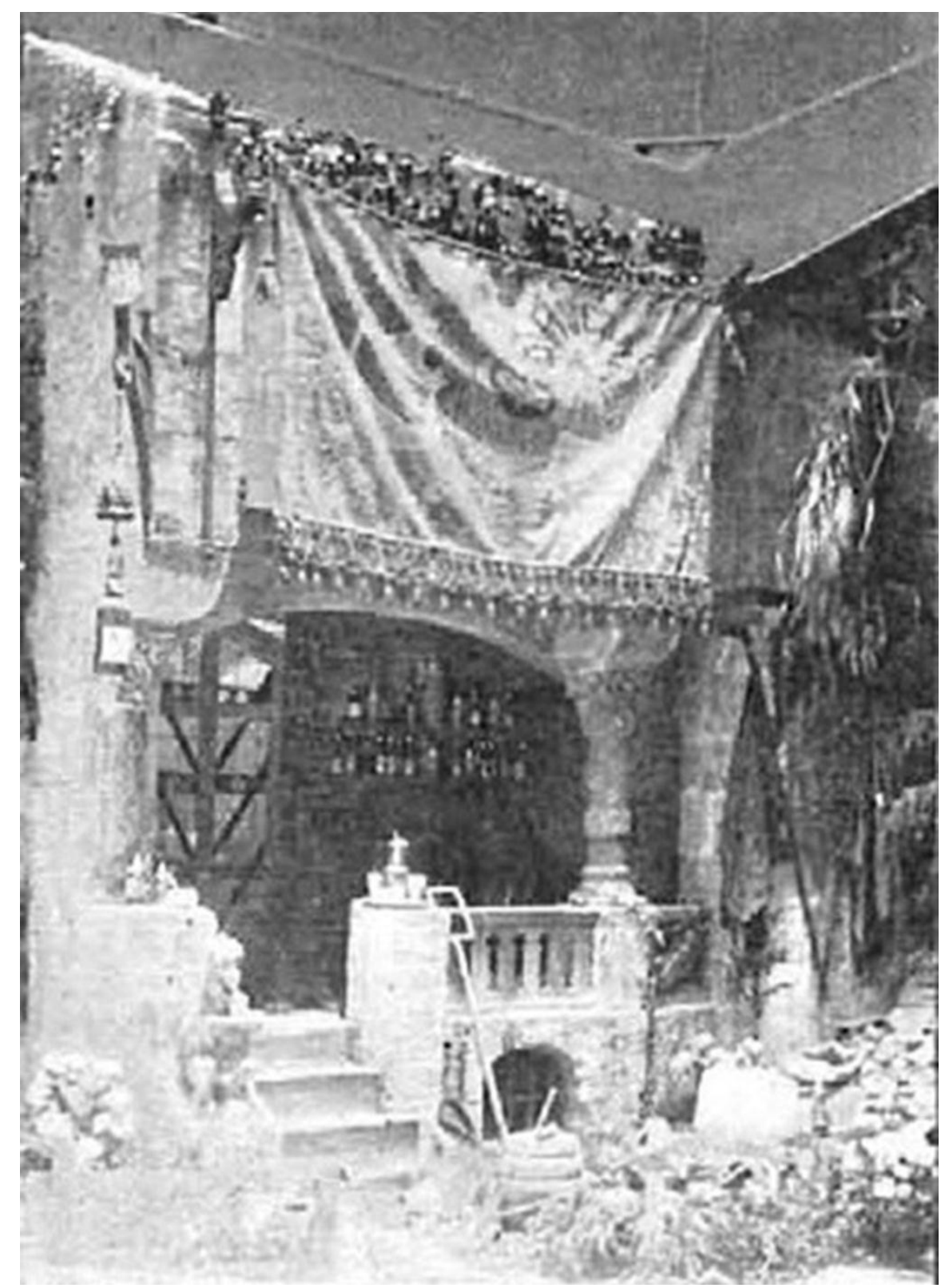

Fig. 2. Instalación de Cervezas Comas, 1897. Fotografía aparecida en La Ilustración artística, 12 de julio de 1897, p.462.

\section{Los Cafés Torino (1900-1902)}

El primer Café Torino (Fig. 3) se establece en los bajos del número 8 de la calle Escudellers, casualmente la casa familiar de Capmany. Es, seguramente, este el motivo por el cual, el dueño del negocio, el turinés Flaminio Mezzalama ${ }^{21}$, entra en contacto con el diseñador. La inauguración, en 1901, fue seguida de un gran éxito de público y en la prensa ${ }^{22}$ se destacaba su decoración y el trabajo de Ricard de Capmany como director de un equipo de artistas y artesanos, muchos de los cuales ya gozaban de reconocido prestigio en la ciudad de Barcelona, y que 
han seguido "la inspiración del señor Capmany" en mobiliario, tapices, pinturas: tapices pintados de Ventosa, con una alegoría de la ciudad de Turín y escenas de la vendimia, escultura decorativa de la sociedad Masana y Buzzi ${ }^{23}$, ebanistería de Calonge e $\mathrm{Hijo}^{24}$, vidrieras de Antonio Gabarrón ${ }^{25}$. Se puede observar la convivencia de elementos típicamente Art Nouveau, como las flores y las formas en coup de fouet, en un ambiente de evocadoras reminiscencias góticas $\mathrm{y}$ germánicas.

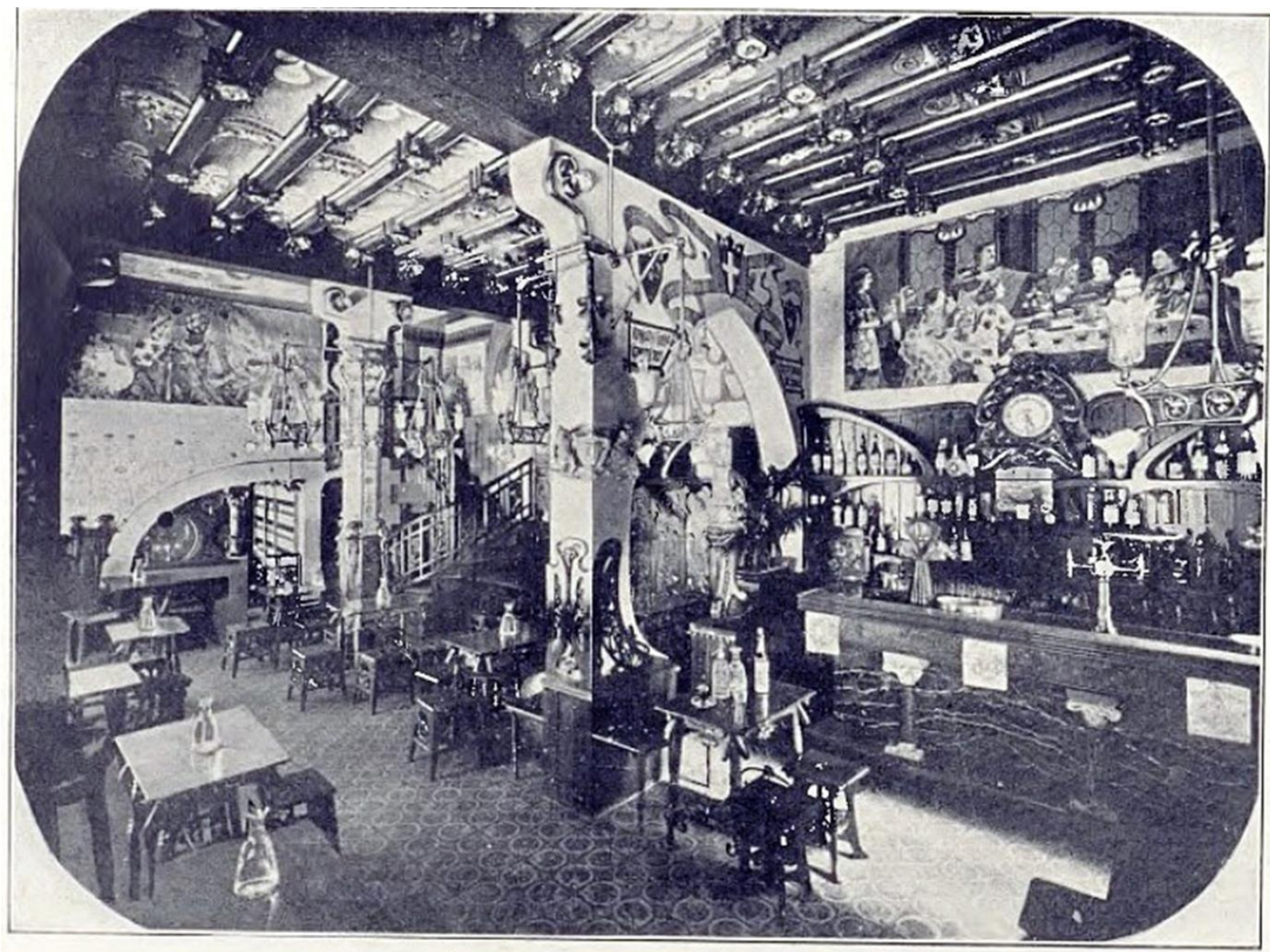

Vista interior del establecimionto

Fig. 3. Interior del café Torino de la calle Escudellers, fotografía aparecida en Hispania, nº 72, abril de 1902, p.162.

El éxito llevó a que pocos meses después se inaugurase otro Torino, esta vez no en la ciudad vieja, sino en el nuevo centro de exhibición de la burguesía: el Eixample, en la céntrica esquina del Paseo de Gracia con Gran Vía, frente a algunas de las casas de la aristocracia de la ciudad: el Palacio Marcet y el Palacio del Marqués de Marianao. Tanto Mezzalama como Capmany decidieron superar el éxito del primer Torino, para ello recurrieron a artesanos, artistas e industriales de primer orden, con algunos ya habían trabajado como las sociedades Calonge e Hijo o Masana y Buzzi; otros eran las empresas artísticas más punteras del momento: Hermenegildo Miralles para los elementos en cartón piedra (azulejos, falsas yeserías y maderas), la forja de Manuel Ballarín, 
vidrieras de Bordalba y Cia, tapices pintados de Ricard Urgell, murales de la sociedad Saumell y García, fundición de Masriera y Campins, lámparas de Fratelli Tosso (Venecia) así como sillería de Thonet ${ }^{26}$. Pero sobretodo destaca la elección de destacados arquitectos para el diseño de los diferentes salones o elementos concretos: Pere Falqués, Antoni Gaudí y Josep Puig i Cadafalch. El éxito fue abrumador y las notas de prensa incidían en la decoración ${ }^{27}$, así que no es de extrañar que se alzase con el premio a la mejor decoración de un local comercial en el concurso anual celebrado por el Ayuntamiento de Barcelona. Una obra en la que se unen las líneas modernistas con elementos pictóricos neo rococó de inspiración alemana, forja goticista o la sala decorada por Gaudí en estilo neo árabe, todo destinado para crear un ambiente de lujo y cosmopolitismo.

\section{Más allá de los cafés Torino}

Después de ese momento son pocos los trabajos como decorador que he podido localizar de Ricard de Capmany. En 1904 es el autor del teatro Las Delicias en la calle Marqués del Duero (actualmente el Paralelo) esquina calle Aldana; según la prensa "s'ha aixecat un bonic edifici de gust modern y d'un aire artistich ben escayent" 28 , obra dirigida por Capmany en su conjunto. En 1911 realiza el decorado para la cena ofrecida en el Salón de Contrataciones de Llotja (una construcción del siglo XIV) por la Cámara de Comercio de la ciudad, con motivo del Congreso Algodonero ${ }^{29}$; y evidentemente sus trabajos en Canet de Mar, caracterizados todos ellos por pertenecer más al ámbito privado que profesional y realizadas sin ningún ánimo comercial o de lucro.

Seguramente, en la desaparición de Capmany de la escena artística debió de influir su carácter, y el de su esposa. Una pareja de la que su único hijo, el pintor Ramon de Capmany nos ha dejado un claro retrato psicológio e ideario político; nos lo describe como un monárquico que recibía al rey Alfonso XIII al grito de "Visca el comte de Barcelona!" 30, reconociéndolo no como rey de España sino como conde de Barcelona, siendo catalanista a su manera.

Era un esteta, que obligaba a un joven Ramon de Capmany, a vestir ropas de tupidos terciopelos llenos de puntillas y cortes de pelo medievales. Una Edad Media mítica de la que se veía heredero, definiéndolo como un caballero medieval, al que nunca le gustó trabajar, un historiador del arte que se dedicó al estudio y catalogación de restos medievales, un romántico del pasado. Para Capmany, estos restos arqueológicos representaban algo más que eslabones de la historia del arte, eran la esencia del país, de su catalanidad. Una Edad Media que se veía, desde el movimiento cultural y político de La Renaixença (El Renacimiento) y en línea con otros movimientos románticos europeos, como el momento histórico de mayor esplendor cultural, político y militar de Cataluña. En 1903 publicó una carta abierta a los alcaldes y rectores de la actual comarca del Maresme, en la cual mostraba su preocupación por la venta y dispersión del patrimonio artístico: "cada objecte antich ó vell, cada pedra trevallada es una lletra del llibre de nostra historia", obras de arte que al conservarlas "faréu Patria, y al fer veure lo qe'es y val Catalunya ab mostras patents, podent fer gala 
de son esplendorós passat"31. Para Capmany la regeneración nacional pasaba por la cultura y recuperación del patrimonio histórico, haciéndolo partícipe del regeneracionismo de parte de la intelectualidad modernista, como Joan Maragall o Santiago Rusiñol ${ }^{32}$. Capmany participa de diferentes empresas culturales del momento, prestando piezas para las exposiciones de arte, así como siendo miembro de las principales entidades culturales de Cataluña como el Ateneu de Barcelona, Centre Excursionista de Catalunya, Junta de Museus de Barcelona, Institut d'Estudis Catalans, fundador de la asociación El Art i els Artistes, llegando a ser, en 1922, presidente del Reial Cercle Artístic. Perfil mucho más complejo que el personaje refinado que reflejan los textos de las necrológicas que glosaban su figura, al que definen como una figura "de singular relieve de la aristocracia catalana por sus prestigios y exquisita caballerosidad, unido todo ello a un trato cordialísimo y a una existencia dedicada en pleno al ejercicio del bien y la caridad"33. La impronta que dejó en Canet de Mar fue evidentemente mayor, y junto a sus cualidades personales se destaca los trabajos que realizó con absoluta generosidad para la villa, "inadvertidos y sencillos detalles, en que don Ricardo, a pesar de la alta nobleza de su estirpe, se ocupaba, con la misma humildad y natural participación de un canetense cualquiera" 34 .

Ricard Capmany se ausenta siempre que puede de la moderna Barcelona, buscando refugio en Canet de Mar, especialmente, en la que sería su torre de marfil, en la que recrearía ese pasado medieval mítico, un espacio y una localidad en la que podía ejercer de señor medieval: el ya mencionado castillo de Santa Florentina.

\section{El castillo de Santa Florentina (1881-1912)}

Ramon de Montaner inicia, a partir de 1881, la reforma de la que había sido la casa familiar, un edifico de los siglos XII a XVI que se podría calificar de masía fortificada. En las primeras intervenciones Ricard de Capmany tiene un papel principal en el acondicionamiento de las habitaciones de la llamada Domus (la parte más antigua del edificio). Ya en 1896 se llama la atención sobre la reja que ha diseñado para la capilla. Realizada por Miquel Soler, un herrero de Canet de Mar, está inspirada en las rejas góticas, coronada por cabezas de perro, flores de cardo y de la pasión ${ }^{35}$, y que aún se conserva en la capilla original. También se han conservado algunos dibujos en los que Capmany distribuye las habitaciones, los muebles o reordena las aberturas de las estancias de la parte medieval del castillo (Fig. 4). 


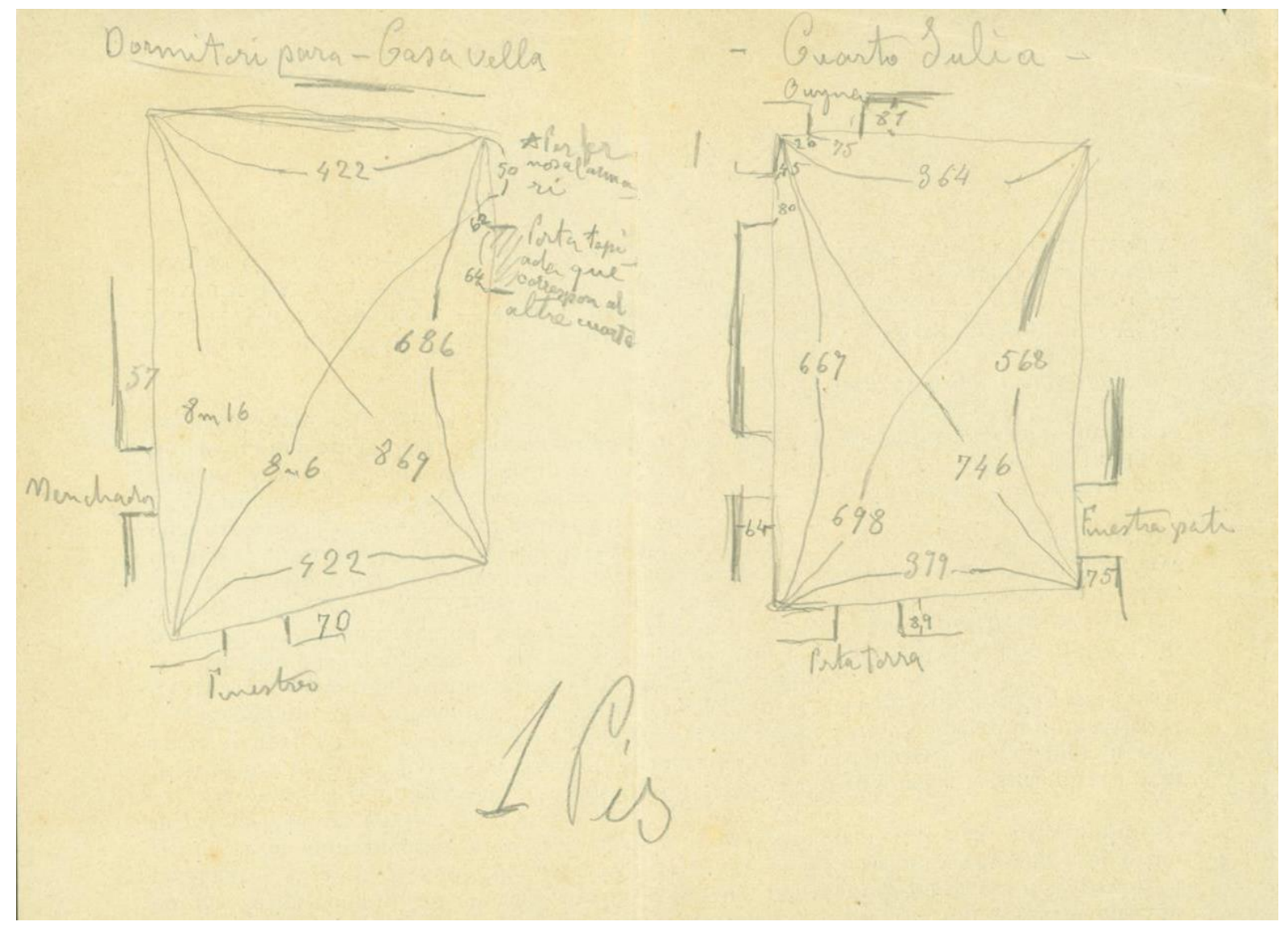

Fig. 4. Dibujo a lápiz con indicaciones para las habitaciones de Júlia de Montaner en la Domus, parte medieval del Castillo de Santa Florentina. Colección particular, Canet de Mar.

Fotografía Arxiu Municipal de Canet de Mar.

A partir de 1899 Ramon de Montaner intensifica el nivel de la reforma, encargando a Domènech i Montaner un ala nueva en estilo neo gótico a partir de la recuperación de materiales auténticos, procedentes de derribos de casonas góticas en Barcelona o la compra de partes del priorato de El Tallat (siglo XV), en Tarragona ${ }^{36}$. En esta parte de la construcción la intervención de Capmany es más difícil de establecer, pero por los indicios no parece que fuese menor. Suya fue la decisión de no trasladar al castillo de Santa Florentina las columnas del templo de Augusto (siglo I) que se conservaban en el interior de un edificio en Barcelona, propiedad también de Ramon de Montaner, oponiéndose a la voluntad de su suegro y el arquitecto Domènech i Montaner; gracias a esta acción aún se pueden contemplar en su lugar original ${ }^{37}$. También, Pere Domènech Roura, hijo de Domènech i Montaner, y arquitecto ayudante en la obra del castillo, apunta en un artículo de $1948^{38}$, que Capmany fue el autor de la decoración interior del castillo, trazando vidrieras, detalles de carpintería o esculturas que se integrasen con las partes antiguas. En algunos casos si que pudo ser el dibujante de lámparas o muebles, en otros quizás se encargó de la elección de temas o de los profesionales que debían llevar a cabo los encargos. 
El interior del conjunto, en general, adopta la apariencia de un espacio medieval que ha pasado por los siglos, con muebles y obras de arte originales de los siglos XIV a XVIII, pertenecientes a la colección de Ramon de Montaner, una de las más importantes de Cataluña en su momento ${ }^{39}$, que se combinan con artes industriales (forja, cerámica, vidrieras, textiles) y algunos muebles de carácter ecléctico y modernista; un interiorismo que actualmente prácticamente ha desaparecido. Así, por ejemplo, las vidrieras fueron realizadas por la casa José Pujol y según se puede observar en el único catálogo conservado de esta empresa $^{40}$, muchas de las vidrieras de Santa Florentina, especialmente todas aquellas con repertorio floral, corresponden a modelos que tenía a la venta la casa Pujol. En otras, como las grandes vidrieras historiadas (un Calvario, la entrega de la Regla del Carmen por el obispo Alberto de Avogadro, una escena cortesana ambientada en el Egipto faraónico y una alegoría de la pintura), el tema pudo ser sugerido por Capmany, pero realizado, probablemente, por los dibujantes de Pujol ${ }^{41}$. Respecto a las cerámicas, ya sean pavimentos o revestimientos murales su diseño correspondería a Domènech i Montaner o sus colaboradores más cercanos, así como algunos elementos de forja de los que se han conservado los proyectos en el fondo documental del arquitecto, que se custodia en el Col legi d'Arquitectes de Catalunya. Respecto a la escultura decorativa esta se debe al dibujo de Capmany ${ }^{42}$, realizada por los talleres escultóricos de Diego Masana y Carlos Flotats ${ }^{43}$. Se trata de la infinidad de detalles que sirvieron para completar e integrar en la construcción las piezas medievales, además de elementos como dinteles de puertas, gárgolas, capiteles, etc. Seguramente también trazó la escena de la gran chimenea, con la representación de la firma, en 1599, del privilegio de villa para Canet de Mar, con la participación de miembros de la familia Montaner ${ }^{4}$. Un trabajo con el que Capmany demostró su "bon gust artístich y la seva erudició arqueológica" 45.

Es en los textiles donde se observa con más probabilidad la mano de Capmany y en algunos muebles de carácter simbólico que hizo construir para un episodio en el que Capmany demostró sus dotes como creador de ambientes, fue la visita en 1908 del rey Alfonso XIII, para la que decoró estancias, diseñó muebles, tejidos y actuó como director de escena de una velada que, según los testigo, hizo viajar a los presentes a la Edad Media.

El rey se hospedó la noche del 4 de noviembre de 1908 en el castillo de Santa Florentina. Para la ocasión se redecoró la Sala del Trono (Fig. 5) y se escenografió una velada medieval ${ }^{46}$. Todo el conjunto fue ampliamente descrito en presa ${ }^{47}$ y gracias a las fotos se puede reconstruir visualmente ${ }^{48}$. 


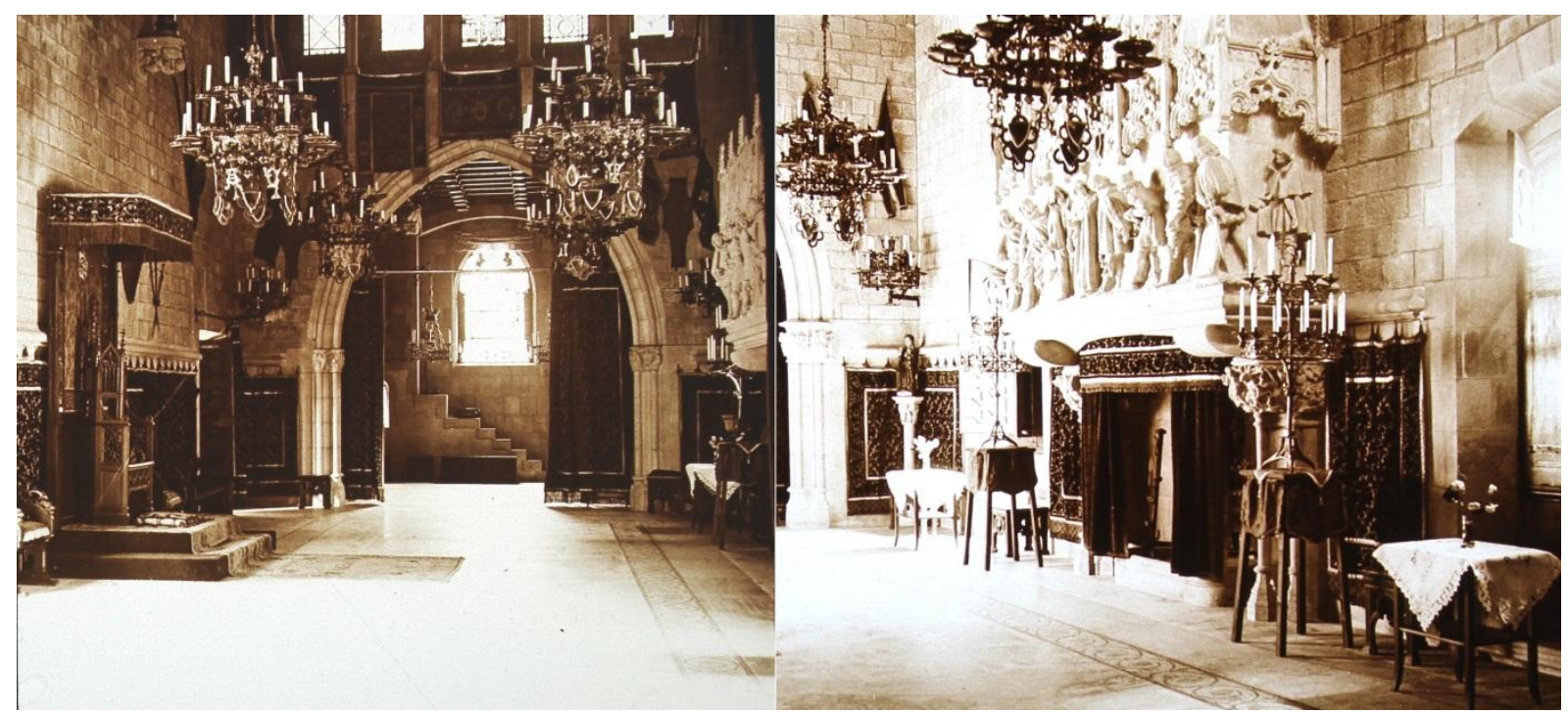

Fig. 5. Interior de la Sala del Trono en 1908. Fotografías anónimas, placas estereoscópicas, 6x13cm, Arxiu Municipal de Canet de Mar.

La sala fue enteramente cubierta de brocados en colores rojos y amarillos, según se puede observar en un dibujo de la sala (probablemente realizado por Domènech i Montaner o su hijo Pere) en el que Capmany sobrepuso las franjas de las diferentes colgaduras, indicando colores, materiales y metros necesarios en una hoja a parte: terciopelo rojo y moaré amarillo (Fig. 6). Seguramente se trataban de tejidos de la casa Hijos de Malvehy ${ }^{49}$. También se confeccionaron unos cojines y reposapiés para los asientos reales, cuyo diseño puede atribuirse a Ricard de Capmany. Sedas, terciopelos, pasamanería se combinan para crear una obras de artes en las que toda la simbología remite a la familia Montaner, sus iniciales rodeadas de dragones (Fig. 7) y flores de lis aparecen en bordados y apliques. En otras obras textiles, Capmany había recurrido para su confección a los miembros femeninos de su familia o a empresas especializadas de Barcelona como Hijos de Miguel Gusí (el Pendón de la Coronación de la Virgen de la Misericordia) o Carlos Casamitjana (los ropajes de los Gigantes de Santa Florentina), en la inspección que se realizó de los dos cojines que actualmente aún se conservan en el castillo de Santa Florentina, no se pudo observar ninguna etiqueta o marca de taller de costura ${ }^{50}$.

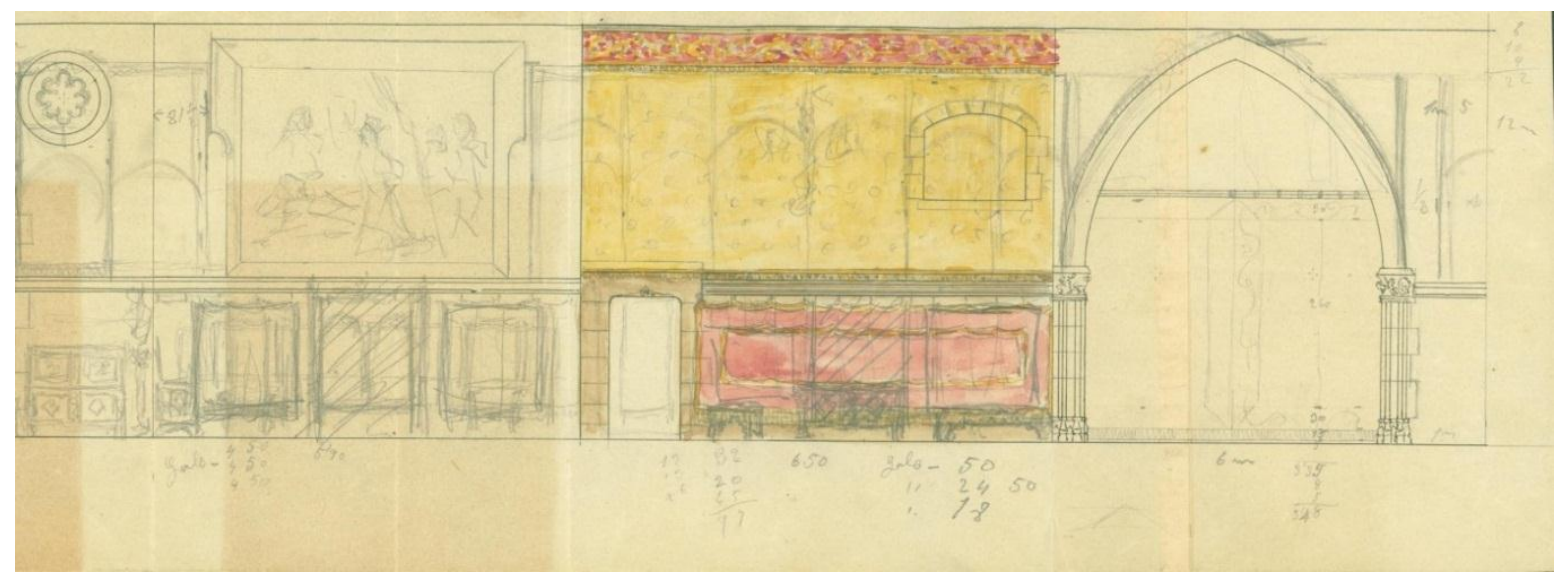

Fig. 6. Dibujo del Salón del Trono con indicaciones de los tipos de telas, colores y metros necesarios para decorarlo. Colección particular, Canet de Mar. Fotografía Arxiu Municipal de Canet de Mar. 


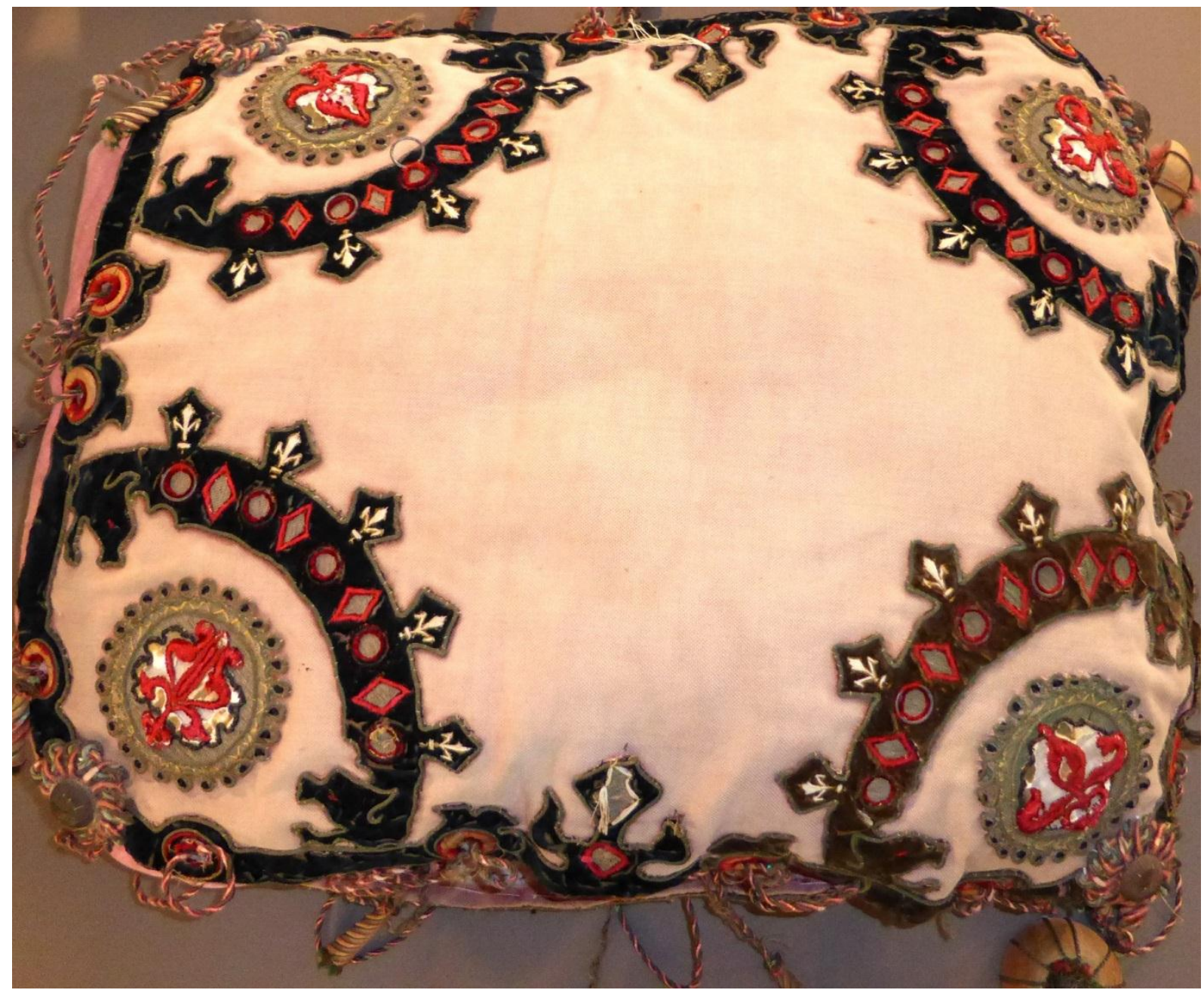

Fig. 7. Cojín realizado en seda, terciopelo, pasamanería, cordón y bordados que se conserva en el castillo de Santa Florentina. Foto V. de la Fuente.

Junto a los muebles ya existentes, de estilo neogótico (taburetes con decoraciones trilobuladas entre las patas, escaños con decoración incisa de hojas de acanto $u$ otros muebles) ${ }^{51}$, el principal elemento de la escenografía preparada para Alfonso XIII fue la confección de un trono para ser ocupado por el rey. Para ello Capmany eligió muy bien el modelo.

No era el primer trono que diseñaba. Para Capmany el último trono catalán era el del rey Martí l'Humà (1356-1410) último rey de la Corona de Aragón y Conde de Barcelona de la dinastía de la Casa de Barcelona. En la Catedral de Barcelona se conserva, como sede de la Custodia, un trono que la tradición a hecho pertenece a este rey de Aragón y conde de Barcelona, Martín I, y que, para Capmany debía permanece vacante hasta la llegada de un nuevo rey legítimo. Es el modelo de trono que utiliza para el desfile de conmemoración del bicentenario de la festividad canetense del Vot de Vila que se realizó en 1903. La carroza estaba presidida por ese trono vacío, rodeada de escudos nobiliarios, al lado del cual, una joven ricamente ataviada, descrita como una matrona por la 
prensa local, aguardaba junto al escudo de Cataluña. La carroza avanzaba tirada por dos quimeras o dragones y se iluminaba por lámparas de queroseno ${ }^{52}$.

Era evidente que este trono no podía estar destinado a Alfonso XIII, así que Capmany, gran conocedor de la historia del arte, tomó como modelo otro de los tronos conocidos de la antigua Corona de Aragón, el que se conservaba en la Cartuja de Valldemossa (Mallorca), aunque, para ser exactos, no era un trono sino una silla abacial del siglo $\mathrm{XV}^{53}$. Capmany realiza un trono prácticamente idéntico, destinado únicamente al rey.

Durante la recepción, el trono se sitúa frente a la gran chimenea del salón; a lo largo de las paredes, cubiertas de colgaduras y tapices de los siglos XVI y XVII, se alinean las sillas, escaños y taburetes para los diferentes invitados. Banderas, escudos, los reflejos de la colección de vidrios y cerámicas de Ramon de Montaner y los dorados de las sillas del siglo XVIII complementan una escena en la que no faltan los discursos y recitados de poesías.

Para la cena de gala el trono preside la mesa en el salón principal; el rey se sitúa enfrentado al único óleo que conforma la decoración, La leyenda del escudo de Catalunya de Pablo Béjar (1891). Al amanecer, el gran sitial se traslada al pequeño comedor, para el desayuno privado del rey (Fig. 8). Una vez el rey se ha marchado, el trono se coloca en el salón principal y es precintado para que nadie más lo vuelva a usar. Al inicio de la Guerra Civil fue destruido.

Una demostración de riqueza con la que la familia Montaner/Capmany demostraba su aprecio a la monarquía, pero, al mismo tiempo su catalanismo. Un esfuerzo que fue recompensado por Alfonso XIII nombrando a Ramon de Montaner primer Conde del Valle de Canet, un título que fue recibido con gran júbilo por toda la familia y que en la prensa provocó las consecuentes sátiras. Por fin la familia se había forjado una historia, una residencia y obtenido un título nobiliario a la altura de sus aspiraciones sociales y su status económico, un espacio en el que se reconocían y en que se daban a conocer a todos sus visitantes ${ }^{54}$. Un logro obtenido, a partes iguales, por la fortuna económica de Ramon de Montaner y la creatividad de Ricard de Capmany. 


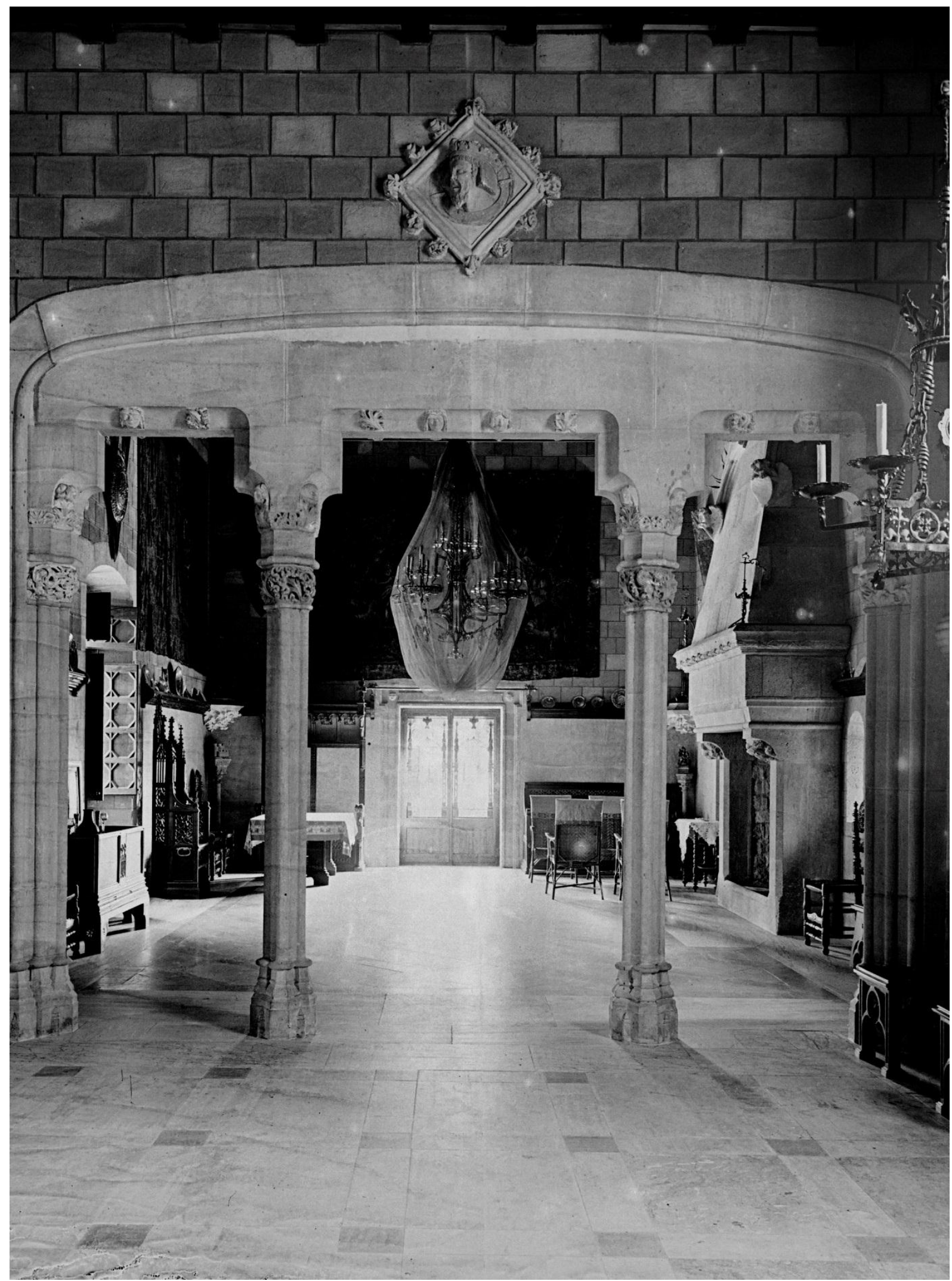

Fig. 8. Fotografía del comedor privado del rey en la década de 1920, una vez el trono fue instalado allí, abandonando el lugar honorífico que durante la década anterior había ocupado en el Salón del Trono. Las colgaduras que adornaban las paredes ya han desaparecido. Autor de la fotografía Joaquim Castells, placa estereoscópica de 6x13cm. Arxiu Municipal de Canet de Mar. 
La idea de escenografía, de un teatro para la vida real, planea sobre el castillo de Santa Florentina desde que se inicia su reforma. Ricard de Capmany y Ramon de Montaner parecen ver en este espacio el escenario en el que realizar sus sueños de grandeza medieval, llegando a utilizar antigüedades junto a elementos decorativos procedentes de fiestas de carnaval en Barcelona. Algunos de los famosos tapices, colgaduras o cuadros que se utilizaban para decorar el patio de armas y los salones del castillo, en las recepciones a personajes ilustres o fiestas familiares, provenían del baile de disfraces celebrado en el Salón de Contrataciones de Llotja en Barcelona, en 1891. Una espectacular decoración, realizada por los mejores artistas de la ciudad, que Ramon de Montaner había comprado al completo ${ }^{55}$.

\section{Conclusiones}

Personaje más complejo que la idea hasta ahora expuesta de él: un proyectista o decorador profesional, en la línea de Salvador Alarma, Josep Pascó, Adrià Gual o Alexandre de Riquer. Se puede decir que, más acorde a su personalidad, Ricard de Capmany actúa como un diletante, trabajando en un círculo inmediato de familiares y actos en los que se implicaba personalmente, creando objetos y espacios únicos; lejos de aceptar retos profesionales por los que iba a recibir un pago en metálico con diseños para la industria (ya fuesen pavimentos hidráulicos, cerámicas, bibelots, estampados textiles o papeles pintados) como Mateo Cullell, Antoni Saló, Francesc Labarta y un largo etcétera. En palabras de Cirici sería uno de aquellos que siendo un "conoisseur (...) y a la postre rico, viajero, culto, entró en liza para propagar aquella idea entre nitzcheriana y wagneriana de que los espíritus selectos están por encima de la regla común (...). El amoralismo aristocrático como destilación de una catarsis libertaria" 56 .

$\mathrm{Su}$ estilo oscila entre la imitación arqueologista de la Edad Media, no exenta de una gran inventiva, que aplica en objetos y espacios en los que los elementos medievales y renacentistas se fusionan con las formas modernistas, como en los Torino o el que se observa en el altar de Sant Josep Oriol ${ }^{57}$. En general, no trata de reproducir objetos o espacios históricamente fidedignos, sino en los que el ambiente, la esencia, nos remitan directamente a un pasado glorioso y mítico, como la escenografía del Salón del Trono para la visita de Alfonso XIII o la corona de la Virgen de la Misericordia que diseñó en 1907, creando un objeto realmente personal. Realizada en plata, esmaltes y piedras preciosas por la casa Carreras de Barcelona está formada por grandes flores de lis que se alternan con ángeles de aire pre rafaelita y alas esmaltadas; en la diadema elementos típicos de las coronas bizantinas, como los pendulia ${ }^{58}$.

Pero es sobretodo un trabajo ligado a su experiencia vital. Su fin no es crear objetos o espacios simplemente bellos, sino que con ellos trata de reconstruir la historia y la personalidad de Cataluña, al mismo tiempo que recrea una identidad familiar. Es la casa como el espacio donde todos los sueños se hacen realidad, una idea íntimamente ligada al modernismo.

Unas obras por las que Ricard de Capmany ha logrado trascender y situarse entre los grandes diseñadores modernistas. 


\section{NOTAS}

${ }^{1}$ Las residencias habituales de Ricard de Capmany, el Palau Montaner en Barcelona y el Castell de Santa
Florentina en Canet de Mar, fueron saqueadas al inicio de la Guerra Civil (1936-1939), perdiéndose gran parte
de la documentación personal.
${ }^{2}$ La fecha de nacimiento es errónea, señala 1873 y no 1871 como es correcto, también está mal datado el Torino
de la calle Escudellers, en 1916 y no en 1901 como corresponde. Respecto a su producción pictórica, califica a
Capmany de paisajista, pero poco conocemos de ella, a parte de unos títulos de óleos presentados en alguna
exposición. Creo que la confunde con la producción del hijo de Ricard de Capmany, Ramon de Capmany,
reputado pintor paisajista.

${ }^{3}$ RÀFOLS, Josep Francesc, Modernismo y modernistas, Barcelona, ed. Destino, 1949. CIRICI, Alexandre, El arte modernista catalán, Barcelona, Ed. Aymá, 1951. MACKAY, David, "Tiendas modernistas en Barcelona, 1882-1922", en Cuadernos de Arquitectura, n 49, Barcelona, 1962. BOHIGAS, Oriol, Reseña y catálogo de la arquitectura modernista, vol. 2, Barcelona, Ed. Lumen, 1973. Galería de Autores. Ruta del Modernismo, Barcelona, Ajuntament de Barcelona/Institut de Paissatge Urbà, 2008.

${ }^{4}$ RÀFOLS, Josep Francesc, "Interiores modernistas" en Cuadernos de arquitectura, $\mathrm{n}^{\circ} 38,4^{\circ}$ trimestre de Barcelona, 1959, pp. 8-11.

${ }^{5}$ CARBONELL, Silvia, "Arquitectes, decoradors i clients. El Modernisme tèxtil a quatre mans: Lluís Domènech i Montaner, Ricard de Capmany, Gaspar Homar i els Tayà" en Datatèxtil, n 31, Terrassa, noviembre 2014, pp. 40-51. En ese artículo se le atribuye un tapiz de Sant Jordi matando al dragón, que en realidad era un tapiz pintado, realizado por Josep Pascó (ver nota 51 en este mismo texto).

${ }^{6}$ FUENTE, Vicente, de la, "Les festes de la Coronació de la Verge de la Misericòrdia de Canet al 1907 i el seu impacte artístic", en Butlletí de la Reial Acadèmia de Belles Arts de Sant Jordi, n XXVII, Barcelona, 2013, pp. $151-158$.

${ }^{7}$ Para una visión global de la obra de Domènech consultar Lluís Domènech i Montaner, en el 50é aniversari de la seva mort, Barcelona, Fundació Lluís Carulla, 1973. Lluís Domènech i Montaner i el director d'orquestra, Barcelona, Fundació Barcelona, Caixa de Barcelona, 1990; Domènech i Montaner, Barcelona, ed. Polígrafa, 1994.

${ }^{8}$ Según consta en el Registro Civil del Ayuntamiento de Barcelona, nacimientos de 1871, asiento 1423.

${ }^{9}$ Antoni de Capmany i Montpalau (Barcelona, 1742- Cádiz, 1813), militar e historiador, siendo su obra más representativa Memorias históricas sobre la marina, comercio, y artes de la antigua ciudad de Barcelona (17791792). Llegó a ser diputado en las Cortes de Cádiz.

${ }^{10} \mathrm{El}$ árbol genealógico de las familias Montaner-Capmany fue confeccionado por el Centre d'Estudis Canetencs para la exposición en la Casa Museu Lluís Domènech i Montaner, en el año 2015, De casa forta a castell, no se editó catálogo, solo un folleto.

${ }^{11}$ Expediente del Arxiu Contemporani de l'Ajuntament de Barcelona, relativos a peticiones de obras mayores, número Fo-272-T/1892.

${ }^{12}$ Catálogo Segunda Exposición General de Bellas Arte: 1894, Barcelona, Imprenta de Henrich y Cía., 1894, p. 190.

${ }^{13}$ Catálogo ilustrado de la III exposición de Bellas Artes e Industrias Artísticas, Barcelona, J. Thomas y Cía., 1896, p. 81.

${ }^{14}$ Catálogo Ilustrado de la IV Exposición Bellas Artes-Industrias Artísticas, Barcelona, Imprenta Henrich y Cía., 1898 , p. 89.

${ }^{15}$ SALA, Teresa-M., "Art, filantropia i diversió, un entramat de relacions a la Barcelona del 1900", Actes XI Congrés d'Història de Barcelona, La ciutat en Xarxa, Barcelona, Ajuntament de Barcelona, 2009. http://w110.bcn.cat/portal/site/ArxiuHistoric (consultado el 20 de junio del 2016)

${ }^{16}$ Los Montaner/Capmany durante los meses de verano y su estancia en el castillo de Santa Florentina, se implicaban en todo tipo de actos de la población, Canet de Mar, en concreto Ricard de Capmany diseñó carrozas, pendones, decorados para fiestas populares y las celebraciones que se realizaban en el castillo: recibimiento de personalidades, bautizos, cumpleaños, etc. Para tener una idea más amplia del patrocinio en este tipo de festejos privados y públicos consultar FUENTE, Vicente, de la; "La fiesta en Canet de Mar: patrocinio e influencia de la familia Montaner" en Emblecat, n 2 2, Barcelona, 2013, pp. 33-46.

${ }^{17}$ Decoración realizada bajo la dirección del escenógrafo Joan Francesc Chia, en el Teatro Lírico, y que mereció los elogios de toda la prensa: "Baile en el Círculo Artístico" en La Dinastía, n $^{\circ}$ 5732, Barcelona, 27 de febrero de 1895, p. 2; "El baile de trajes del Círculo Artístico", en La Ilustración Artística, no 688, Barcelona, 4 de marzo de 1895, pp. 182-184; "Tercer baile de trajes del Círculo Artístic", en La Vanguardia, Barcelona, 26 de febrero 
de 1895, pp. 3-4. Como curiosidad, señalar que Ricard de Capmany acudió al baile disfrazado de cortesano del emperador bizantino Andrónico según reza la "Crónica general de la quincena” en El Salón de la Moda, n 292, Barcelona, 4 de marzo de 1895, pp. 38-39.

18 "Gegants" en La Costa de Llevant, n 40, Canet de Mar, 5 de octubre de 1902, pp. 10-11; "Fiestas de la Merced", Hispania, $\mathrm{n}^{\circ}$ 88, Barcelona, 15 octubre 1902, pp. 425-428; "La cavalcada histórica, artística e industrial" en La Veu de Catalunya, Barcelona, 4 de octubre de 1902, pp. 4-5-6; COSTA, Juan. "Els gegants i el nanos de Canet" en Pedracastell, no 24, Canet de Mar, mayo 1948, pp. 1-3.

19 “Exposición Industrial Barcelona 1987” en Blanco y Negro, Madrid, 3 de julio de 1897, p. 14; "La industria española en el Palacio de Bellas Artes de Barcelona", en La Ilustración artística, $\mathrm{n}^{\circ}$ 811, Barcelona, 12 de julio de 1897, pp. 462-463; "Exposición de industriales", en Industrias e Invenciones, n 16, Barcelona, 16 de octubre de 1897, p. 145.

${ }^{20}$ CABANA, Francesc, Damm, 125 años de 1876 a 2001, Barcelona, Damm S.A., 2001; GARCIA, Xavier, Los orígenes y la implantación de la industria cervecera en España, siglo XVI - 1913, Tesis doctoral inédita, Universitat de Barcelona, año 2013, en http://www.tdx.cat/handle/10803/130897 (consultado el 20 de agosto del 2016).

${ }^{21}$ Mezzalama se había instalado en Barcelona en 1893 como gerente de una pequeña fábrica que los vermuts Martini \& Rossi habían establecido en el pueblo de Sant Martí de Provençals, a fin de evitar la Ley de Aranceles. Con esa ley proteccionista, que gravaba las importaciones, España pretendía proteger a los fabricantes españoles contra los productos extranjeros. La fábrica, con inicialmente 38 trabajadores, pretendía abastecer el mercado español y los de América del Sur, Filipinas y Norte de África, SOLER, José, Exposición de las industrias creadas, introducidas y desarrolladas en España al amparo del arancel de 1891. Catálogo general, Barcelona, Imprenta y litografía de José Conill Sala, 1897, p. 147.

22 "Vermouth Torino" en Hispania, no 76, Barcelona, 15 de abril de 1902, pp. 161-162.

${ }^{23}$ Establecidos en la calle Universidad (actual Enric granados) funcionaron desde 1898 hasta 1909, ver en FUENTE, Vicente, de la; "Diego Masana" en Els Escultors de Lluís Domènech i Montaner: Arnau, Gargallo $i$ Masana, Canet de Mar, Casa Museu Lluís Domènech i Montaner, 2015, pp. 16-23; FUENTE, Vicente de la, "Diego Masana i Majó. Un artista modernista entre Barcelona i l'Argentina" en Butlletí de la Reial Acadèmia de Belles Arts de Sant Jordi, vol. XXX, Barcelona, 2016 (en prensa).

${ }^{24}$ Establecidos en la calle Diputación 19, RODRÍGUEZ, Leire, "Los talleres de ebanistería en Barcelona (18751914), en Estudi del Moble, no 14, Barcelona, 2011, pp. 26-29.

${ }^{25}$ Establecido en la calle Tallers 4, es citado por GIL, Núria, "El taller de vitralls modernista Rigalt, Granell $i$ Cia (1890-1931)", Tesis Doctoral inédita, Universitat de Barcelona, año 2015, p. 110, en http://diposit.ub.edu/dspace/bitstream/2445/54691/1/01.NGF_TESI.pdf (consultada el 18 de septiembre del 2016).

${ }^{26}$ Para las principales industrias artísticas modernistas ver SALA, Teresa-M., "Creación, producción y comercio" en El Modernismo, Manresa, Angle Editorial, 2008, pp. 64-225; Modernismo. Arte, talleres, industrias, Barcelona, Ed. Invisibles, 2015.

27 "Un nuevo establecimiento", en Hispania, no 90, Barcelona, 15 de noviembre de 1902. pp. 478-480; "El establecimiento Torino", en La Ilustración Artística, no 1081, Barcelona, 24 de noviembre 1902, pp. 774-775; "Palacio del vermouth", en Pluma y Lápiz, no 104, Barcelona, 19 de octubre de 1902, p. 513; "El Torino premiado", en Pluma y Lápiz, n 179, Barcelona, 3 de abril de 1903, p. 13. También en MARTINELL, César, "Otra obra de Gaudí olvidada en sus biografía. Salón en el desaparecido bar Torino", en La Vanguardia, Barcelona, 3 de noviembre de 1966, p. 50. Para la intervención de Hermegildo Miralles en los salones decorados por Gaudí y Puig i Cadafalch ver QUINEY, Aitor, Hermenegildo Miralles, arts gràfiques i enquadernació, Barcelona, Biblioteca de Catalunya, 2005.

28 "Notícies d'espectacles" en La Veu de Catalunya, edición de la mañana, Barcelona, 6 de junio de 1904, p. 4. "se ha levantado un bonito edificio de gusto moderno y con un muy adecuado aire artístico", (traducción del autor).

${ }^{29}$ La Vanguardia, Barcelona, 26 de mayo de 1911, p. 2.

${ }^{30}$ PERMANYER, Lluís, "Un señor de Barcelona: Ramón de Capmany”, en La Vanguardia, Barcelona, 8 de noviembre de 1987, p. 31. El segundo texto en el cual Ramon de Capmany habla de su padre es una monografía dedicada al propio Ramon de Capmany como pintor, SALCEDO, Antonio, Ramon de Capmany: Sempiternae Voces, Sabadell, Ed. Ausa, 1994.

${ }^{31}$ CAPMANY, Ricard, “Als senyors Alcaldes y Rectors dels pobles", en La Costa de Llevant, no 1, Canet de Mar, 11 de enero de 1903, p. 21. "cada objeto antiguo o viejo, cada piedra trabajada es una letra del libro de nuestra historia", "haréis Patria, y hacer ver lo que es y lo que vale Cataluña con muestras patentes, pudiendo hacer gala de su esplendoroso pasado" (traducción del autor). 
${ }^{32}$ Ver para este aspecto Rusiñol desconegut, Sitges, Ajuntament de Sitges, 2006, en concreto los capítulos SALA, Teresa.-M., "Sota el signe de la melancolia: l'ideari estètic", pp. 20-33 y CASACUBERTA, Margarita, "L'intel·lectual modernista", pp. 188-201.

${ }^{33}$ La Vanguardia, Barcelona, 3 de septiembre de 1947, p. 7.

34 "Sepelio de un gran señor", en Pedracastell, no 16, Canet de Mar, octubre 1947, p. 1.

35 "Una obra d'Art", en La Costa de Llevant, n' 43, Canet de Mar, 25 de octubre de 1896, p. 11.

${ }^{36}$ No entraremos en la arquitectura, sino que solo nos centraremos en el papel de Ricard de Capmany, para saber más de la construcción de Santa Florentina consultar Canet de Mar, Història i Arquitectura. El patrimoni catalogat, Canet de Mar, Ajuntament de Canet de Mar-Centre d'Estudis Canetencs-Edicions Els 2 Pins, 2009, pp. 199-203; FUENTE, de la, Vicente, "Muebles e interiores en Canet de Mar", en Res Mobilis, vol. 3, n 3, Oviedo, 2014, pp. 57-73; FUENTE, Vicente de la, "El Castell de Santa Florentina", en Joies del Modernisme català. Espais interiors, Barcelona, Enciclopèdia Catalana, 2014, pp. 110-115. Para la arquitectura neogótica en Cataluña y especialmente su uso en la rehabilitación, reconstrucción y engrandecimientos de casas familiares de la nueva burguesía ver LACUESTA, Raquel, Restauració monumental a Catalunya (segles XIX $i$ XX). Les aportacions de la Diputació de Barcelona, Barcelona, Diputació de Barcelona, 2000, en www.diba.cat/spal/restauracio-monumental-a-catalunya (consultado el 3 de septiembre del 2016). Para una descripción de la parte medieval, antes del inicio de la reforma de Domènech i Montaner ver LÓPEZ DE SAGREDO, Jorge, "El Castillo de Santa Florentina", en La Vanguardia, Barcelona, 15 de septiembre de 1894, p. 1 .

37 “La Reforma del Centre Excursionista, projectada per Lluís Domènech", en La Ilustració catalana, $\mathrm{n}^{\circ} 125$, Barcelona, 22 de octubre de 1905, pp. 677-679; VIDAL, Eduard, "En César August Torras", en Butlletí del Centre Excursionista de Catalunya, no 346, Barcelona, noviembre 1923, pp. 313-314.

${ }^{38}$ DOMÈNECH, Pere, "El Castillo de Santa Florentina", en Pedracastell, ${ }^{\circ}$ 30, Canet de Mar, noviembre de 1948, pp. 1-2.

${ }^{39}$ GARCÍA, Antonio, "La colección de Don Ramón de Montaner", en La Vanguardia, Barcelona, 22 de junio de 1892 , p. 4.

${ }^{40}$ Fabricación de vidrieras artísticas José Pujol y Cia, Barcelona, Imprenta Litografía de Blasi, ca. 1895.

${ }^{41}$ Este es un punto que actualmente está trabajando la Doctora en Historia del Arte y experta en vidrieras, Núria Gil.

${ }^{42}$ PAGÉS, Pere, "El castell senyorial de Santa Florentina", en La Veu de Catalunya, Barcelona, 4 de noviembre de 1908 (edición tarde), pp. 1-2. En este texto se ofrece una exhaustiva descripción de la decoración, así como del trabajo de Ricard de Capmany.

${ }^{43}$ FLOTATS, Josep Maria, "Els Flotats una nissaga d'escultors modernistes" en El Sot de l'Aubó, no 9, Canet de Mar, 2004, pp. 34-39.

${ }^{44}$ Entre las esculturas en yeso que se conservaron en el castillo tras las obras y que habían servido como modelo para la escultura ornamental, se encontraron algunos pertenecientes a la chimenea. Actualmente estos yesos se conservan en la Casa museu Lluís Domènech i Montaner de Canet de Mar. Son obra de Diego Masana.

${ }^{45}$ PAGÉS, Pere, "El castell senyorial...", cit. p. 1. "Su buen gusto artístico y su erudición arqueológica" (traducción del autor).

${ }^{46}$ Para esta velada, los poemas recitados, menú, etc. ver ROVIRA, Josep, "Fa quasi cent anys de la visita del rei Alfons XIII a Canet", en El Sot de l'Aubó, no 18, Canet de Mar, 2006, pp. 34-36; MANENT, Albert, "Un poema de Josep Carner llegit davant del rei Alfons XIII”, en Els Marges, n 83, Barcelona, 2007, pp. 95-98.

47 "El rey en Cataluña", en Los Debates, Tortosa, 6 de noviembre de 1908, pp. 1-2; "El Rey en Cataluña", en $L a$ Época, Madrid, 5 de noviembre de 1908, p. 2; “S.M. el Rey D. Alfonso XIII en Cataluña”, en La Ilustración Artística, Barcelona, 16 de noviembre de 1908, pp. 748-756; "El rei a Catalunya", en El Poble català, Barcelona, 6 de noviembre de 1908, p. 2; "El Rey en Cataluña", en La Vanguardia, Barcelona, 5 de noviembre de 1908, p. 9; "El castell senyorial de Santa Florentina", en La Veu de Catalunya, Barcelona, 4 de noviembre de 1908 (ed. Tarde), p. 2.

${ }^{48}$ Además de las fotografías aparecidas en la prensa contemporánea, el Centre Excursionista de Catalunya dispone de un gran número de fotografías del castillo, realizadas por sus miembros a los largo de varios años, por lo que es posible ver los cambios de las principales Salas entre 1908 y 1920. Además tienen entre sus colecciones imágenes del castillo en el Arxiu Mas de Barcelona y el Arxiu Municipal de Canet de Mar, este último posee una interesante serie de placas de vidrio, algunas anónimas, otras del fotógrafo Joaquim Castells realizadas entre 1907-1920. Las fotografías que ilustran este texto, en concreto las dos que forman la Fig. 5, son una reciente adquisición del Arxiu Municipal de Canet de Mar, seguramente están realizadas muy poco tiempo después de la cena de gala, conservando gran parte de los ornamentos y disposición de los muebles. Lamentablemente aún no se ha podido realizar su limpieza y escaneo digital. Una vez se haya procedido a ello, será mucho más fácil ver los estampados de los tejidos, los encajes y otros detalles. La imagen para este artículo 
se ha obtenido fotografiando directamente las placas de vidrio. Agradezco la ayuda y colaboración de Yolanda Serrano, del Arxiu Municipal de Canet de Mar.

${ }^{49}$ CARBONELL, Silvia, Arquitectes, decoradors i clients..., cit. p. 41.

${ }^{50}$ En una fotografía conservada en el Arxiu Mas de Barcelona, número de negativo C-39246, y fechada en 1923 , se puede ver un arcón gótico sobre el que reposan los dos cojines que mencionamos junto a otros varios modelos. Por lo que se puede observar en las fotografías inmediatamente posteriores a la real visita, los dos conservados sirvieron para el asiento y como reposapiés del trono.

51 No hay ninguna indicación de quien pudo realizar estos muebles, solo una carta conservada entre el escenógrafo Francesc Soler i Rovirosa y Domènech i Montaner en la cual se hace referencia a un carpintero de Barcelona, llamado Sánchez, que trabaja para Domènech i Montaner y el "Sr. Ramon" (posiblemente Ramon de Montaner), respecto a unos trabajos que no puede avanzar más. La carta está fechada en Barcelona en 1891 y se conserva en Arxiu Municipal de Canet de Mar. Dichos trabajos pueden hacer referencia a la finalización del Palacio Montaner de Barcelona o unas primerísimas intervenciones en Santa Florentina. Un Sánchez que quizás sea el mismo ebanista, Juan Sánchez que recoge RODRÍGUEZ, Leire, "Talleres ebanistería en Barcelona..." cit., p. 29.

${ }^{52}$ Ver FUENTE, Vicente de la, “La fiesta en el Canet modernista...” cit., p. 42.

${ }^{53}$ La foto de la silla abacial había sido publicada en Arte decorativo revista mensual eco del Centro de Artes Decorativas de Barcelona, $\mathrm{n}^{\circ}$ 2, Barcelona, noviembre 1894, pp. 9-10. Ver también PIJOAN, Josep, Historia general del arte, vol. II, Barcelona, Ed. Salvat, 1916; FEDUCHI, Luis, Barcelona, Ed. Polígrafa, 1969; BAUÇA, Concepció, La Real Cartuja de Jesús de Nazaret de Valldemossa, Palma de Mallorca, Universitat de les Illes Balears, 2008; El Moble a Mallorca: segles XIII-XX. Estat de la qüestió, Palma de Mallorca, Consell Insular Mallorca, 2011.

${ }^{54}$ Para la casa como reflejo de la personalidad del promotor ver SALA, Teresa-M., "Nuevos espacios domésticos" en El Modernismo, Manresa, Angle Editorial, 2008, pp. 64-225; NICOLÁS, Dora, "La casa modernista como espacio doméstico para los sueños”, en CREIXELL, Rosa M.; SALA, Teresa-M., Espais interiors: la casa i l'art (siglos XVIII-XIX), Barcelona, Publicaciones de la Universitat de Barcelona, 2007, pp. 157-164.

${ }^{55}$ Ver en FUENTE, Vicente, de la; "La fiesta en Canet”, cit., p. 38. También "Lo Ball del Cércol Artístich" en La Ilustració Catalana, $\mathrm{n}^{\circ}$ 254, Barcelona, 15 de febrero de 1891, p. 43. Para ilustraciones ver "El $2^{\circ}$ Baile de Trajes del Círculo Artístico" en un suplemento ilustrado de La Vanguardia, Barcelona, 9 de febrero de 1891 y "El baile del Círculo Artístico" en La Ilustración Hispano Americana, Barcelona, 22 febrero 1891, pp. 120-126127, donde parecen grabados en el que se puede observar esta decoración en el Salón de Llotja. Se distinguen claramente piezas mencionadas en las descripciones del castillo, como el tapiz de Sant Jordi matando al dragón, de Josep Pascó y la alegoría El Genio del Arte, esta última realizada por Josep Cusachs y retocada por Ricard de Capmany (ya siendo propiedad de Ramon de Montaner) que, añadiendo algunos elementos (una bandera catalana y unos grilletes rotos), la convirtió en un alegato catalanista. De todo el conjunto, esta última pieza es la única que actualmente se conserva aún en el castillo.

${ }^{56}$ CIRICI, Alexandre, “A través de los objetos modernistas”, en El Modernismo en España, Madrid, Dirección General de Bellas Artes del Ministerio de Educación y Cultura, Comisariado General de Exposiciones, 1969, pp. 27-30, en concreto p. 30.

${ }^{57}$ Realizado para la parroquia de Sant Pau i Sant Pere de Canet de Mar en 1910, fue destruido al inicio de la Guerra Civil (1936).

${ }^{58}$ Durante la Guerra Civil fue despojada de las piedras preciosas, reapareciendo años después en Francia y devuelta a Canet de Mar donde se conserva actualmente.

Fecha de recepción: 1 de octubre de 2016

Fecha de revisión: 8 de noviembre de 2016

Fecha de aceptación: 15 de noviembre de 2016 